\title{
PHARMACEUTICAL CARE PRACTICE IN THE COMMUNITY PHARMACY BY UTILIZING PROBLEM-BASED LEARNING IN REFLECTIVE PEDAGOGY PARADIGM METHOD
}

\author{
Titien Siwi Hartayu, Yosef Wijoyo*), Maria Wisnu Donowati \\ Faculty of Pharmacy, Universitas Sanata Dharma, Campus 3 Paingan, Maguwoharjo, Depok, \\ Sleman, Yogyakarta, 55282
}

Received July 25, 2020; Accepted February 8, 2021

\begin{abstract}
This study follows the previous study entitle Problem-based Learning (PBL) in reflective pedagogy paradigm (RPP): Innovative learning in pharmaceutical care, which identified the learning material as complicated. This study aimed to provide an appropriate method for performing pharmacy management and pharmaceutical care in Community Pharmacy. Data collection was done using an assessment instrument to identify student's achievement. The previous study encompasses preceptors and students in developing learning material, which cause it more valid and reliable to be implemented. The study was conducted in Yogyakarta, Surakarta, and Semarang city. The effectiveness of the learning material was shown by the grade of student's achievement in learning outcome and the clear state with confidence in the expression of reflection and action-plan. Most of the students in the 3 cities achieved an excellent grade both in the problem-solving field, and presentation of the assignment. The students reflected that the learning material is simple and suitable in practicing pharmaceutical care and pharmacy management, moreover, they can state their plan to work as a Community Pharmacist withconfidence. Therefore, PBL in the RPP method is ready to be used in practicing pharmaceutical care in the Community Pharmacy.
\end{abstract}

Keywords: learning process; pharmaceutical care; pharmacist; problem-based learning; reflective pedagogy paradigm.

\section{INTRODUCTION}

In Indonesia, pharmaceutical care should be provided by pharmacists based on the Indonesian pharmacist standard of competence according to the regulation of Indonesian Health Minister No.73/2016 (Minister of Health, 2016). In achieving the competencies, Pharmacists should have good knowledge, attitude, and practice in caring for the patients, and they also should have goodcommunication skills to educate the customers (Aurelia, 2013; Handayani et al., 2009; Hartayu et al., 2013). However, based on the result of some studies regarding customer satisfaction towards pharmaceutical care performance, most of the customers stated that they were not satisfied, and pharmaceutical care performance should be improved (Hartayu et al., 2013). Therefore, the School of Pharmacy, especially the Pharmacist profession program should improve thelearning process in achieving the Pharmacists' competence in performing a good pharmaceutical care practice. According to those facts, an innovation of the learning process in pharmaceutical care has been done by infusing problem-based learning (PBL) in the reflective pedagogy paradigm (RPP).

Problem-based learning (PBL) is a common method used in the learning processto conduct pharmaceutical care and pharmacy management in the community pharmacy (Hartayu et al., 2018). PBL embraces the principles of good learning and teaching. It is

*Corresponding author: Yosef Wijoyo

Email: yosefw@usd.ac.id 
student-directed, which encourages selfsufficiency and is a preparation for life-long learning, and also promotes active and deep learning (Tais et al., 2014). PBL often includes or requires peer teaching, which encourages students to digest information, so that they can present, explain, and utilize it confidently. Reusing knowledge reinforces the processes of remembering and digesting (Hmelo-Silver, 2004). In the end, PBL encourages, and indeed requires, reflection on the learning process: how did it go this time, and next time will the team do it more efficiently and more effectively? On the other hand, RPP was chosen due to the characteristic of the learning process that is used, i.e. RPP has been proven as an effective strategy to improve the quality of personality, including personality character building in humanity, such as compassion and to be a responsible person. RPP is appropriate to use in higher education such as the Faculty of Pharmacy (Defeo, 2009; Hayes, 2006), to improve the students' ability to reflect (Avoy et al., 2012; Crable et al., 2010; Hise, 2012), and RPP is also can be used to improve the understanding of Pharmacotherapy and communication skill (Defeo, 2009; Hayes, 2006; Wijoyo et al., 2016). In the point ofview about pharmaceutical care practice, the innovation of the learning process is aimed specially to achieve learning outcomes such as 1. the ability to propose business plan; 2 . the ability to evaluate medicines management; 3 . the ability of dispensing and educating patient in rational used of medicines; and 4. the ability of proposing Home Pharmacy care (Hartayu et al., 2018; Setiawan et al., 2010).

RPP is known as a paradigm and the way to improve the quality of personality and character building with activity cycle: Context-experience-reflection-action-

evaluation (JSEA, 1993; Metts, 1995). Therefore, PBL in RPP was designed by developing an Initiating-trigger case based on the real case as a problem to solve (PBL) and also as a context in the activity cycle, which will experience students in performing pharmaceutical care. Based on the experience in problem-solving through the real case, the students were then should write some reflection, and then make some plan to act, and finally, they should evaluate what have they done (Cycle of RPP). The preliminary study regarding PBL in RPP that has been done in 3 cities, i.e. Yogyakarta, Surakarta, and Semarang city in Indonesia, showed the achievement of the students' ability in understanding both the theory and performing in pharmaceutical care (Hartayu et al., 2018), and indicate that the strengthening of the learning process of PBL in RPP is the comprehension of reflection, which result in the ability to integrate competence, conscience, and compassion. Moreover, the key to succeed in pharmaceutical care performance is the appropriate initiating-trigger case. Unfortunately, the preliminary study also found that the initiating-trigger case was indicated unreal and complicated (Hartayu et al., 2018), therefore, revising and re-testing the Initiating-trigger case are needed. Based on the above facts regarding the inappropriately learning material that has been used to conduct PBL in RPP, the study is aimed to provide an appropriate method for performing pharmacy management and pharmaceutical care in Community Pharmacy.

\section{METHODS}

The steps of the study are developing an initiating-trigger case, study semester plan, and assessment instrument. The study starts by inviting preceptors who will be involved in the study as a field supervisor, to conduct a focus group discussion (FGD). FGD among preceptors and academic supervisors results in approval of prescription criteria which will be used as the Initiating-trigger case. Criteria of the prescription are the prescription that is usually served in the community pharmacy which has a common problem regarding medicines used. Based on the approval of the prescription's criteria, a scenario as the Initiating-trigger case was then be developed. Before it was used, the scenario was distributed to the students for the language tests.

Regarding the study semester plan, this study used the same study semester plan as the previous study, based on the reflective 
pedagogy paradigm cycle, i.e. contextexperience-reflection-action-evaluation.

Context is fulfilled by the scenario based on the common prescription from the community pharmacy as the Initiating-trigger case. Experience is fulfilled by using problembased learning to construct students' knowledge and experiences in problemsolving, and then the reflection is fulfilled by Wijoyo's reflection list (Wijoyo et al., 2016).
Every student has to propose a community pharmacy business and home pharmacy care plan as an action in Pharmacist's managerial and clinical role. The evaluation was done by using an assessment instrument. The scopesof the learning process are developed based on the Competence Standard of Indonesian Pharmacist according to the $\mathrm{MOH}$ No.73/2016 and are described in Table 1 as follow:

Table 1. Cycle I of PBL in RPP scopes

\begin{tabular}{ccl}
\hline No & Stage & \\
\hline 1 & Context & $\begin{array}{l}\text { The scope of the learning material is mainly about the Standard of Pharmaceutical care } \\
\text { according to the MOH no. 73/2016. }\end{array}$ \\
\hline 2 & Experiences & $\begin{array}{l}\text { The active learning process is done by using the PBL in the RPP method and represented } \\
\text { by } 4 \text { Initiating-trigger cases which are contained of the learning material relevant to the } \\
\text { context. }\end{array}$ \\
\hline 3 & Reflection & $\begin{array}{l}\text { The student reflection process is carried out with the principle of "past-present-future" } \\
\text { which reflects an understanding and ability to select the solution strategic and also be } \\
\text { responsible for the decision they have made. }\end{array}$ \\
\hline 4 & Action & $\begin{array}{l}\text { Action is a follow up of experiences that they have gotten as a responsibility towards what } \\
\text { have they done through the paperwork, presentation, and discussion. }\end{array}$ \\
\hline 5 & Evaluation & $\begin{array}{l}\text { Academic Supervisors and preceptors evaluate student's learning outcomes by using an } \\
\text { assessment instrument. }\end{array}$ \\
\hline
\end{tabular}

Assessment instrument was developed based on the activity in the PBL in RPP method which contains 7 steps such as 1 . identify the problems; 2 . hypothesis development; 3. identify the needs of data and provided data; 4 . looking for data needed; 5. active self-learning; 6. sharing and pooling; and, 7. evaluating. Reflection was done after the 7 steps have been done. Preceptors and students filled up the reflection list. During 2 months internship, the students conducted an assignment regarding the PBL in RPP activities in the first month, and then in the second month, the students evaluated what have they done in the first month. The evaluation was done by presented the business plan, inventory control, dispensing, patient education, and home pharmacy care plan. The assessment instrument which was used, has been tested using a peer simulation method, and the assessment is done based on the abilityto explain the result of a problem which was identified and the solution problem, including the appropriateness and systematically analysis; relevance of references; effective communication and teamwork; and, should be on time in submitting those assignments. The achievement grade is divided into 4 categories, i.e. excellent $(>75)$; good (70-75); average (65-69); and poor $(<65)$. The highest contribution to the grade is the content of the paperwork $(60 \%)$. The steps of the studies summarize is described in Figure 1 entitle fishbone of the study as follow: 


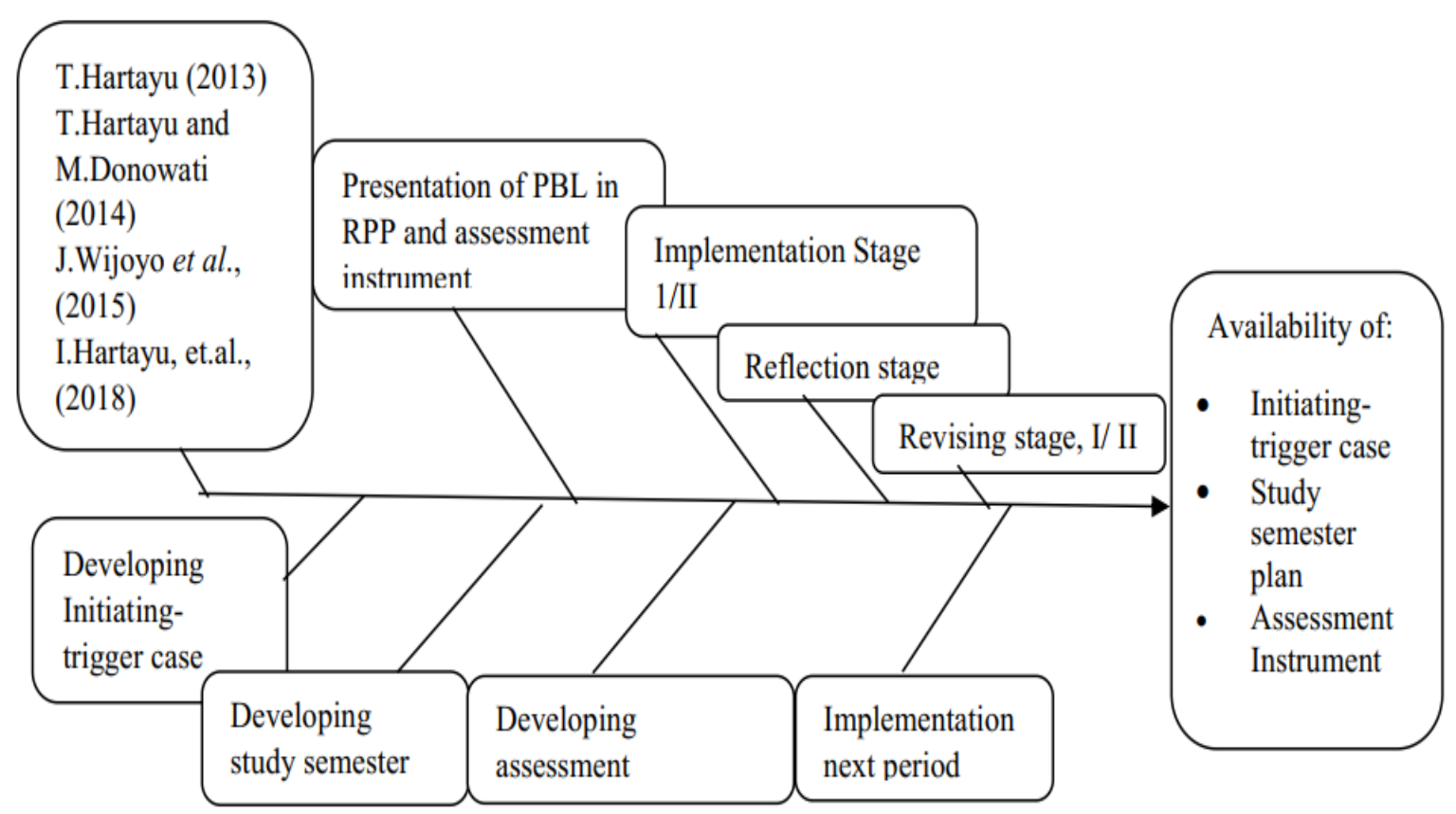

Figure 1. Fishbone of the study.

\section{ETHICAL CLEARANCE}

Ethical clearance of the study is stated by certificate no. 454/C.16/ FK/2017 of the Ethics Committee of the Faculty of Medicines Duta Wacana Christian University, Yogyakarta, Indonesia.

\section{RESULTS AND DISCUSSION}

The results of the study are divided into 4 assessments, i.e. 1. Implementation of the PBL in RPP method; 2. Assessment of Students 'reflection; 3. Reflection on the research implementation; and, 4. Evaluation of PBL in RPP method.

\section{Implementation of the PBL in RPP Method}

The difference of stage 2 (2018) compare with stage 1 (2017) regarding the implementation of the PBL in the RPP method is the learning material in stage 2 has been directed linked to the real problem they faced in the field, through the direct involvement of the preceptors in proposing the learning material. Consequently, the learning process instage 2 is better due to the balance of the difficulty level that should be solved and the time of internship availability. The learningoutcomes evaluation regarding the achievement of grade point towards students' paperwork are presented on Table 2, as follow: 
Table 2. Students grade point achievement on learning outcomes based on the paper work

\begin{tabular}{|c|c|c|c|c|}
\hline $\begin{array}{l}\text { Initiating- } \\
\text { trigger } \\
\text { Case }\end{array}$ & Topic & KFA Yogyakarta & KFA Semarang & KFA Surakarta \\
\hline & & \multicolumn{3}{|c|}{ Supervisor / Preceptor } \\
\hline 1 & $\begin{array}{lcl}\text { Feasibility } & \text { study } & \text { to run the } \\
\text { Business } & \text { in } & \text { Community } \\
\text { Pharmacy } & & \\
\end{array}$ & $72 / 70$ & $80 / 77$ & \\
\hline 2 & $\begin{array}{l}\text { Pharmaceutical } \\
\text { performance }\end{array}$ & $76 / 76$ & $78 / 78$ & $75 / 78$ \\
\hline 3 & $\begin{array}{l}\text { Pharmacy management } \\
\text { (Inventory control) }\end{array}$ & $80 / 78$ & $78 / 77$ & $74 / 77$ \\
\hline 4 & $\begin{array}{l}\text { Home pharmacy care for } \\
\text { diabetic patient }\end{array}$ & $80 / 84$ & $80 / 82$ & \\
\hline
\end{tabular}

KFA: Kimia Farma Apotek

Supervisor/preceptor rate is $0-100$ scale grade point. This grading point was based on a rating rubric toward student paperwork. Students' grade point $72 / 70$ means the first supervisor gave 72 points and the second gave 70 toward student paperwork.

\section{Assessment of Students' Reflection on the PBL in RPP First Cycle Implementation}

In the reflection stage, the students are given some questions as a guideline to write self-reflection after they practiced in the pharmacy management and pharmaceuticalcare aspect. The questions are:

1. Put forward the experience that you have experienced (write down things related to the goal learning process, and relevance to your profession)

2. Knowledge: What knowledge you have gained after implement the learning material during theprofessional practice program, is it useful to support your profession in thefuture?

3. Life values: What values of life have you gained after practice the PBL inthe RPP method?
4. Write down the action plan as afollowup to the knowledge and values of life, which you have gained afterpracticing PBL in the RPP method.

Answering the four questions, most students in Yogyakarta, Surakarta, and Semarang City are stated that the method experienced them in problem-solving, and relevant to the Pharmacist's responsibility. They experienced how to propose the business plan, inventory control, compounding and dispensing, improving communication skills, home pharmacy care, improving selfconfidence and networking, performing pharmaceutical care with confidence, and more responsible for their task. They have a willingness to be a responsible and proactive person. Based on the evaluation of the paperwork and students' reflection, students showed excellent performance in identifying problems, problem-solving strategy, and inventory control in the management cycle. The students' reflection was quantified based on the grading rubric in Wijoyo's (2016) experiment. The result of students' reflection assessment is described in Table 3 as follow: 
Table 3. Average point of students' reflection

\begin{tabular}{|c|c|c|c|}
\hline \multirow[b]{2}{*}{ Reflection questions } & \multicolumn{3}{|c|}{ Average Point (score max.5) } \\
\hline & Surakarta & Yogyakarta & Semarang \\
\hline \multirow{2}{*}{$\begin{array}{l}\text { 1. Put forward the learning experience that you have } \\
\text { experienced (write down things related to the goal } \\
\text { learning process, and relevance to your profession) }\end{array}$} & & & \\
\hline & 4 & 3.3 & 3.3 \\
\hline $\begin{array}{l}\text { 2. Knowledge: What knowledge you have gained after } \\
\text { implement the learning material during the } \\
\text { professional practice program, is it useful to support } \\
\text { your profession in the future? }\end{array}$ & 3 & 4 & 3 \\
\hline $\begin{array}{l}\text { 3. Life values: What values of life have you gained } \\
\text { after practice the PBL in the RPP method? }\end{array}$ & 4 & 5 & 5 \\
\hline $\begin{array}{l}\text { 4. Write down the action plan as a follow-up to the } \\
\text { knowledge and values of life, which you have } \\
\text { gained after practicing PBL in the RPP method. }\end{array}$ & 4 & 3 & 3 \\
\hline
\end{tabular}

\section{Reflection on the Research Implementation}

After conducting the first cycle of PBL in RPP activities, academic supervisors and preceptors meet up to reflect the outcomes of the learning process. The reflection result can be described as follows:

Preceptors in Surakarta City stated that students have been able to solve the problem by utilizing the Initiating-trigger case in the Home Pharmacy Care and providing a creative and realistic solution in Pharmaceutical Care and also in Pharmacy management. However, there are still groups of students who provide less realistic solutions, especially in a feasibility study to run the business of Community Pharmacy. On the other hand, academic supervisors observed that based on the achievement of scores, students have demonstrated their ability to extract data and information; determine and solve the problems which they have found.

In Yogyakarta City preceptors expressed that students have been able to solve the problem by exploring data and information thoroughly during conducting field observation, reviewing problems from thesight, and provide solutions fairly well. It is necessary to improve the sharpness of the analysis, especially in solving the problem of the pharmacy business feasibility study, that has not good yet and still in the average category; from the point view of performing pharmaceutical care and Home pharmacy care, students have been adequate and successful. Academic supervisors observed that in general, students who were practice in Yogyakarta City showed their effort and ability to solve the problems and be able to relate the problem with practicing in pharmaceutical care by using the PBL in RPP method. However, there were still groups of students who had not to provide information in detail about the problem. Therefore, the report of the solution has not accurate yet (regarding the Initiating- trigger case of the business plan feasibility study). Appreciation was given to the students who demonstrated mastery of the problem and were able to perform home pharmacy care and pharmaceutical care properly.

Regarding students who were practice in Semarang City, the preceptors opinionated that students demonstrated a strong willingness to learn, good pharmacological knowledge, and adaptability to the field conditions. However, there were stillweaknesses in the mastery of pharmacy management material and the ability to conduct pharmaceutical care. Management capabilities were still weak in aspects of the business plan feasibility study and pharmacy management. On the other hand, academic supervisors noticed that by gaining new experience during the internship in the community pharmacy, students were able to 
determine some problems that often arise in performing pharmaceutical care. They were not only hearing, but also directly observed and at the same time tried to practice the theories acquired.

\section{Evaluation PBL in RPP Method}

Finally, The PBL in RPP method was evaluated by the preceptors based on the students' learning outcomes, and the evaluation result is described in Table 4 as follow:

Table 4. Evaluation of PBL in RPP based on the student's learning outcomes

\begin{tabular}{|c|c|c|}
\hline No & Preceptors in & Evaluation Results \\
\hline 1 & $\begin{array}{l}\text { Yogyakarta } \\
\text { City }\end{array}$ & $\begin{array}{l}\text { a. The Initiating-trigger case is based on the daily activities which were } \\
\text { carried out by the Pharmacist at the Community Pharmacy. } \\
\text { b. The existence of an Initiating-trigger case makes it easy for all } \\
\text { preceptors to choose relevant material to be taught and practiced at the } \\
\text { Community Pharmacy by the students during the Pharmacists } \\
\text { profession practice program. } \\
\text { c. It can be utilized as Information about the composition of portfolio } \\
\text { assessment in assessing student activity. }\end{array}$ \\
\hline 2 & Surakarta City & $\begin{array}{l}\text { a. The existence of an Initiating-trigger case facilitates the depth of the } \\
\text { mentoring process to the material learning about pharmacy } \\
\text { management. } \\
\text { b. All of the Initiating-trigger cases are ready to be implemented during } \\
\text { the Pharmacists profession practice program. }\end{array}$ \\
\hline 3 & Semarang City & $\begin{array}{l}\text { a. The existence of an Initiating-trigger case becomes a guideline in the } \\
\text { process of the Pharmacists profession practice program. } \\
\text { b. Highly appreciate the result of learning material ravishment. } \\
\text { c. The Initiating-trigger case is more realistic and easier to be } \\
\text { implemented. }\end{array}$ \\
\hline
\end{tabular}

In terms of supporting the realization of plenary health services in the field of Pharmacy, the government issued pharmaceutical care standards (MOH No. 1027/2004 which has been updated to the regulation of the MOH no. 35/2014) ( $\mathrm{MOH}$ Regulation, 2004; $\mathrm{MOH}$ Regulation, 2014) where the role of pharmacists is very clearly regulated. Unfortunately, until nowadays, even though the quantity of pharmacists has increased significantly every year, the expected role has not been recognized yet. The role of pharmacists in health care services is needed to support the achievement of therapeutic goals. In supporting the achievement of therapeutic goals, a Pharmacist is expected to have good knowledge and skills in explaining the purpose of treatment, ways of storage, possible side effects, and how to cope with the adverse drug reaction (Aurelia, 2013; Hartayu et al., 2013). The result of the study showed that almost all of the students in Semarang city achieved an excellent categorize in proposing the business plan, performing pharmaceutical care, conducting inventory control, andproposing the home pharmacy care plan. On the other hand, students in Yogyakarta city only achieved a good categorize in proposing the business plan however, they also achieved an excellent grade in the 3 others, such as performing pharmaceutical care, inventory control, and home pharmacy care. Comparing with students in those two cities, students in Surakarta city achieved an excellent grade in performing pharmaceutical care and inventory control. Unfortunately, the community pharmacy in Surakarta city did not conduct the business plan and home pharmacy care due to the human resources constraint.

The student's reflection stated that the learning material is simple and realistic, because they used the learning based on the 
real case, therefore, it would be very useful in the future job. The reflection was written in a very clear statement and structure. The action plan was stated in a very confident by $70 \%$ of the students that they are willing to work as a Community Pharmacist, and the rest of the amount wrote still in a normative manner, i.e. "I want to work based on my passion" without mentioning what is their passion.

One of the studies stated that PBL has not always been successful (Glew, 2003), and the other study mentioned that educational research has found it difficult to demonstrate positive effects of PBL on outcomes such as knowledge, critical thinking, reflective practice, and teamwork (Hounsell et al., 2002). However, based on the result of this study including the method evaluation by the preceptors, showed, that PBL in the RPP method is effective in the learning process to improve student's knowledge and skills in performing pharmacy management and pharmaceutical care, and also effective in improving character building such ashumanity, having a sense of compassion and be a responsible person (Hartayu et al., 2018; Hise, 2012). Regarding the unsuccessful of conducting PBL, the reason is probably as a result of its not being implemented properly rather than there is a basic flaw in the method (Barrows, 1986; Hughes et al., 2003). In addition, the result showed that the strength of the method is the modifying of PBL that was infused in the Reflective pedagogy paradigm. The result of the study is also indicating that these findings for pharmaceutical education are consistent with recent research in nursing (Shin et al., 2013), medical (Tayyeb, 2013), dental education (Huang et al., 2013), and in the Universities learning process (Defeo, 2009; Hayes, 2006). The way of working of the RPP itself is to shape the student's personality by providing an experience of humanitarian values, then proceed with reflecting on the experiences. Therefore, the PBL in RPP method can increase student's reflective abilities (Avoy et al., 2012; Crable et al., 2010; Hise, 2012). The PBL in RPP method is also suitable as a model to make the students can integrate competence, conscience, and compassion in the field of their profession include improving an understanding of pharmacotherapy and communication skills of pharmacist profession students (Wijoyo et al., 2016).

In this study, the PBL in RPP method is implemented in the learning process of pharmacist profession practice program at the community pharmacy, with a focus on the 4 fields, such as the preparation of a business plan feasibility study to run the business of a community pharmacy; inventory control of medicines and medical devices; pharmaceutical care; and home pharmacy care plan. Due to the PBL in RPP method encourages students to think about and solve real problems, it is likely to aid their use of knowledge in clinical situations, helps develop their clinical reasoning, and encourage selfdirected learning throughout their professional careers (Handayani et al., 2009; Jones, 2006). In healthcare fields, these skills are highly desirable and valuable.

Based on these findings, the PBL in RPP method shows the ability to make prospective pharmacists as a learner to learn thoroughly in implementing the theory into practice, and reinforced by a comprehensive reflection process, and lead the Pharmacist Graduates to be able in integrating competence, conscience and compassion (Glew, 2003; Hise et al., 2010; Mann et al., 2009) these findings can be an answered of the previous study which demonstrated that by utilizing PBL alone, students perform better academically; even though there was no data that can infer this improvement results in better professional (Tais et al., 2014).

This makes PBL in the RPP method the preferred education method for healthcare courses. Unfortunately, the study did not measure the possibility of increasing cost regarding the implementation of the PBLin the RPP method, however, other study found that the main barriers for implementing PBL are a teacher and staff training and a necessary reduction in class size, which could increase the cost of pharmacy education (Finucane et al., 1998; Jones, 2006). On the other hand, other study found that PBL and 
traditional curriculum costs arecomparable, and the main difference is the way teachers and other faculty personnel carry out their duties because the PBL program requires greater engagement with students (Donner et al., 1990; Hamdy et al., 2011) which is similar with PBL in RPP method implementation.

The key success in implementing PBL in RPP can be described as follow, In the group sessions, the students may have to work quite hard and be active in a different activity than sitting taking notes in a lecture. They may also worry about their performance in a group where all the students have different knowledge and skills. This situation motivates students to better prepare before class begins. In conducting PBL in the RPP method, the instructor helps the students develop problem-solving skills, selfdirected learning, collaboration skills, and intrinsic motivation, which led students to identify what they know, what they need to know, and how and where to access new information they need. In consequently, this PBL in RPP method can be an important tool in healthcare care education, in which students learn by working with real-life cases.

\section{CONCLUSION}

PBL in the RPP method is effective to be used in the learning process. The key to success in utilizing this method, are: should be focused on the main problem of practicing in pharmacy management and pharmaceuticalcare that will support in performing pharmacy services during pharmacy profession program, and the discussion among the Academic supervisors and preceptors should beconducted intensively during preparing and evaluating the program.

\section{CONFLICT OF INTEREST}

The authors declare there is no conflict of interest.

\section{REFERENCES}

Aurelia, E., 2013. Expectations and Beliefs of Pharmacy Customers on the Role of Pharmacists in West Surabaya. Calyptra, 2 (1), 1-20.
Avoy, M.Mc., Crowe, T., Lotz, R., Truka, B., 2012. The Influence of the Ignatian Pedagogical Paradigm on Instructors Integrating It into Undergraduate Courses in the College of Professional Studies at Marquette University. Jesuit Higher Education, 1(2), 82-105.

Barrows, H.S., 1986. A Taxonomy of Problembased Learning Methods. Medical Education, 20(6), 481-486.

Crable, E., Brodzinski, J., 2010. Designing Online Business Courses Using the Ignatian Pedagogical Paradigm. Unpublished Research, Xavier University.

Defeo, J.A., 2009. Old Wine in a New Skin: Ignatian Pedagogy, Compatible with and Contributing to Jesuit Higher Education, Fordham University.

Donner, R.S., Bickley, H., 1990. Problembased Learning: an Assessment of Its Feasibility and Cost. Human Pathology, 21(9), 881-885.

Finucane, P.M., Johnson, S.M., Prideaux, D.J., 1998. Problem-based Learning: Its Rationale and Efficacy. Medical Journal of Australia, 168(9), 445-448.

Glew, R., 2003. The Problem with Problembased Medical Education: Promises Not Kept. Biochem Mol Biol Education, 31, 52-56.

Hamdy, H., Agamy, E., 2011. Is Running a Problem-based Learning Curriculum More Expensive than a Traditional Subject-based Curriculum? Medical Teacher, 33(9), 509-514.

Handayani, R.S., Raharni., Gitawati, R., 2009. Persepsi Konsumen Apotek terhadap Pelayanan Apotek di Tiga Kota di Indonesia. Makara Kesehatan, 13(1), 22-26.

Hartayu, T.S., Widayati, A., Wijoyo, Y., 2013. Improving Drug Information Service for Diabetic Patients. IJCP, 2(3), 102111.

Hartayu, T.S., Wijoyo, Y., Donowati, M.W., 2018. Problem-based Learning in Reflective Pedagogy Paradigm: Innovative Learning in Pharmaceutical 
Care. J Young Pharm, 10 (2) Suppl: s1s5.

Hayes, C.X., 2006. Paradoxes, Parallels and Pedagogy: A Case Study of Ignatian Pedagogy and Teacher's Perception of Its Implementation in Australian Jesuit Schools. Australian Catholic University, Victoria.

Hise, J.V., Massey, D.W., 2010. Applying the Ignatian Pedagogical Paradigm to the Creation of an Accounting Ethics Course. J Bus Ethics, 96(3),453-465.

Hise, J.V., 2012. Transformative Education Using Ignatian Pedagogy to Teach Business Ethics. Fairfield University.

Hmelo-Silver, C.E., 2004. "Problem-based Learning: What and How do Students Learn?" Educational Psychology Review, 16(3), 235-266.

Hounsell, D., McCune, V., 2002. Teachinglearning Environments in Undergraduate Biology: Initial Perspectives and Finding. Occasional Report No. 2, Enhancing Teaching and Learning Project, URL http://www.ed.ac.uk/etl., (accesed 01.10.19).

Huang, B., Zheng, L., Li, C., Li, L., Yu, H., 2013. Effectiveness of Problem-based Learning in Chinese Dental Education:a Meta-analysis. Journal of Dental Education, 77, 377-383.

Hughes, I.E., Wood, E.J., 2003. Does Problembased Learning Work and Whose Fault Is It if it Doesn't?.Biochem Mol Biol Education, 31, 257 - 259.

Jesuit Secondary Education Association (JSEA)., 1993, Ignatian Pedagogy Practical Approach. Originallypublished as a monograph: Reprinted as Appendix B in The Jesuit Ratio Studiorum of 1599: $400^{\text {th }}$ Anniversary Perspectives.

Jones, R.W., 2006. Problem-based Learning: Description, Advantages,

Disadvantages, Scenarios, and Facilitation. Anesthesia and Intensive Care, 34(4), 485-488.

Mann, K., Gordon, J., MacLeod, A., 2009. Reflections and Reflective Practice in
Health Professions Education: A Systematic Review. Adv in Health SciEducation, 14(4), 595-621.

Metts, R.E., 1995. Ignatius Knew. Jesuit Secondary Education Association (JSEA), Washington DC.

Minister of health, 2004. Minister of health regulation No.1027/MOH/SK/IX/2004, URL:http://hukor.kemkes.go.id/hukor/k epmenkes/2004, (accessed 01.10.19).

Minister of Health., 2014. Minister of health regulation no. 35/MOH/SK/2014, The Standard of Pharmacy Services in the Community Pharmacy in Indonesia. Ministry of Health Indonesia, Jakarta.

Minister of Health, 2016. The Indonesian Pharmacist standard of competence regulation. Ministry of Health Indonesia, Jakarta.

Setiawan, D., Hasanmihardja, M., Mahatir, A., 2010. Pengaruh Pelayanan Kefarmasian terhadap Kepuasan Konsumen Apotek di Kabupaten Tegal. Jurnal Farmasi Indonesia, 5(2), 100-108.

Shin, I.S., Kim, J.H., 2013. The Effect of Problem-based Learning in Nursing Education: a Meta-analysis. Advances in Health Sciences Education, 18(5), 1103-1120.

Tais, F.G., Marcus, T.S., Celiane, S.N., Laura, M.R, Mauricio, G.P., 2014. ProblemBased Learning in Pharmaceutical Education: A Systematic Review and Meta-Analysis. The Scientific World Journal, vol. 2014, 1-7.

Tayyeb, R., 2013. Effectiveness of Problembased Learning as an InstructionalTool for Acquisition of Content Knowledge and Promotion of Critical Thinking among Medical Students. Journal of the College of Physicians and Surgeons Pakistan, 23, 42- 46.

Wijoyo, Y., Rahayu, G.R., Dwiprahasto, I., 2016. Evaluation on Pharmacotherapy Learning Strategies based on Reflective Pedagogy Paradigm in Pharmacists' Education Program Sanata Dharma University. IJPCR, 8(5), 493-499. 